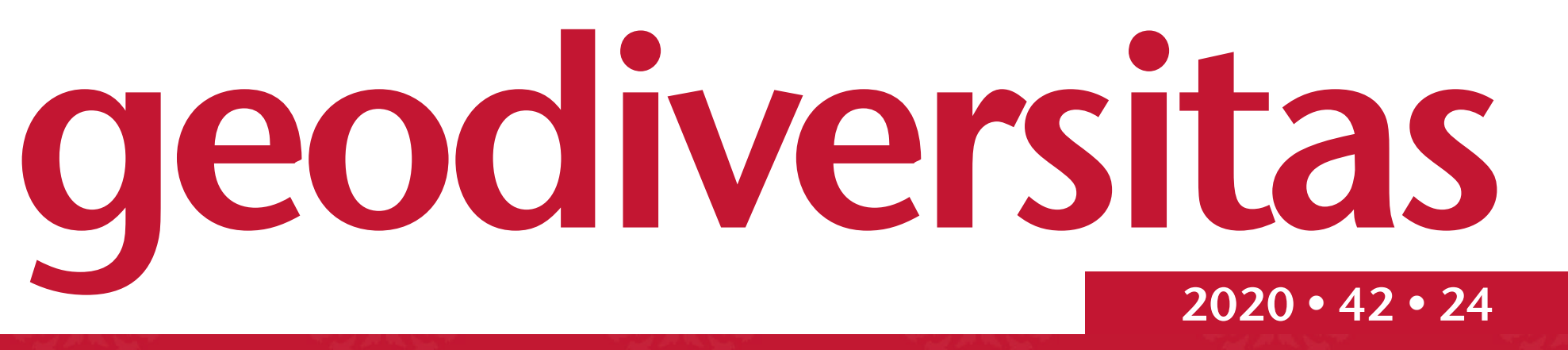

Trophic position of some Late Devonian-Carboniferous (Mississippian) conodonts revealed on carbon organic matter isotope signatures: a case study of the East European basin

Andrey V. ZHURAVLEV 
DiReCteur de LA PUblication / PUBLICATION DIRECTOR : Bruno David,

Président du Muséum national d'Histoire naturelle

RÉDACTEUR EN CHEF / EDITOR-IN-CHIEF: Didier Merle

ASSISTANT DE RÉDACTION / ASSISTANT EDITOR: Emmanuel Côtez (geodiv@mnhn.fr)

Mise EN PAGE / PAGE LAYOUT: Emmanuel Côtez

COMITÉ SCIENTIFIQUE / SCIENTIFIC BOARD:

Christine Argot (Muséum national d'Histoire naturelle, Paris)

Beatrix Azanza (Museo Nacional de Ciencias Naturales, Madrid)

Raymond L. Bernor (Howard University, Washington DC)

Alain Blieck (chercheur CNRS retraité, Haubourdin)

Henning Blom (Uppsala University)

Jean Broutin (Sorbonne Université, Paris, retraité)

Gaël Clément (Muséum national d'Histoire naturelle, Paris)

Ted Daeschler (Academy of Natural Sciences, Philadelphie)

Bruno David (Muséum national d'Histoire naturelle, Paris)

Gregory D. Edgecombe (The Natural History Museum, Londres)

Ursula Göhlich (Natural History Museum Vienna)

Jin Meng (American Museum of Natural History, New York)

Brigitte Meyer-Berthaud (CIRAD, Montpellier)

Zhu Min (Chinese Academy of Sciences, Pékin)

Isabelle Rouget (Muséum national d'Histoire naturelle, Paris)

Sevket Sen (Muséum national d'Histoire naturelle, Paris, retraité)

Stanislav Štamberg (Museum of Eastern Bohemia, Hradec Králové)

Paul Taylor (The Natural History Museum, Londres, retraité)

COUVERTURE / COVER:

Réalisée à partir des Figures de l'article/Made from the Figures of the article.

Geodiversitas est indexé dans / Geodiversitas is indexed in:

- Science Citation Index Expanded (SciSearch ${ }^{\circledR}$ )

- ISI Alerting Services ${ }^{\circledR}$

- Current Contents ${ }^{\circledR}$ / Physical, Chemical, and Earth Sciences ${ }^{\circledR}$

- Scopus ${ }^{\circledR}$

Geodiversitas est distribué en version électronique par / Geodiversitas is distributed electronically by:

- BioOne ${ }^{\circledR}$ (http://www.bioone.org)

Les articles ainsi que les nouveautés nomenclaturales publiés dans Geodiversitas sont référencés par / Articles and nomenclatural novelties published in Geodiversitas are referenced by:

- ZooBank ${ }^{\circledR}$ (http://zoobank.org)

Geodiversitas est une revue en flux continu publiée par les Publications scientifiques du Muséum, Paris Geodiversitas is a fast track journal published by the Museum Science Press, Paris

Les Publications scientifiques du Muséum publient aussi / The Museum Science Press also publish: Adansonia, Zoosystema, Anthropozoologica, European Journal of Taxonomy, Naturae, Cryptogamie sous-sections Algologie, Bryologie, Mycologie, Comptes Rendus Palevol

Diffusion - Publications scientifiques Muséum national d'Histoire naturelle

CP $41-57$ rue Cuvier F-75231 Paris cedex 05 (France)

Tél. : 33 (0)1 40794805 / Fax: 33 (0)14079 3840

diff.pub@mnhn.fr / http://sciencepress.mnhn.fr

(C) Publications scientifiques du Muséum national d'Histoire naturelle, Paris, 2020

ISSN (imprimé / print): 1280-9659/ ISSN (électronique / electronic): 1638-9395 


\section{Trophic position of some Late Devonian-Carboniferous (Mississippian) conodonts revealed on carbon organic matter isotope signatures: a case study of the East European basin}

KEY WORDS

Conodonts,

Late Devonian,

Mississippian $\delta^{13} \mathrm{C}_{\text {org }}$

palaeoecology,
MOTS CLÉS

Conodontes, Dévonien supérieur, Mississippien $\delta^{13} \mathrm{C}_{\text {org }}$

paléoécologie, position trophique.
urn:Isid:zoobank.org:pub:7228A44F-082D-47AE-A12C-E01DA3009307

Zhuravlev A. V. 2020. - Trophic position of some Late Devonian-Carboniferous (Mississippian) conodonts revealed on carbon organic matter isotope signatures: a case study of the East European basin. Geodiversitas 42 (24): 443-453. https://doi.org/10.5252/geodiversitas2020v42a24. http://geodiversitas.com/42/24

\section{ABSTRACT}

An isotopic investigation of organic matter of the Late Devonian-Carboniferous (Mississippian) conodont elements of various morphology was carried out. $\delta 13 \mathrm{C}_{\text {org }}$ values of conodont elements measured in this study range from $-32.6 \%$ to $-22.4 \%$, with an average value of $-26.1 \pm 4.8 \%$. The study taxa represent four types of conodont apparatus, which differ one from another by morphology of P1 elements. In spite of apparently different morphology all the studied conodonts possess close ${ }^{13} \mathrm{C}_{\text {org }}$ values. Taxonomic control on the carbon isotope composition is insufficient as well. High consistency of the carbon isotope composition of conodont organic matter suggests that the Late Devonian and Carboniferous (Mississippian) conodonts occupied similar trophic levels. Quite low $\delta^{13} C_{\text {org }}$ values in conodont organic matter allow supposing that conodonts were low level consumers, probably seston and plankton feeders.

\section{RÉSUMÉ}

Position trophique de certains conodontes du Dévonien supérieur et du Carbonifere (Mississippian) révélée par des signatures d'isotopes de matière organique carbone: étude de cas du bassin de l'Europe de l'Est. Une étude isotopique de la matière organique d'éléments de conodontes du Dévonien supérieur-Carbonifere (Mississippien) de morphologie différente a été réalisée. Les valeurs de $\delta 13 \mathrm{C}_{\text {org }}$ des éléments de conodontes mesurées dans cette étude vont de $-32,6 \%$ à $-22,4 \%$ avec une valeur moyenne de $-26,1 \pm 4,8 \%$. Les taxons étudiés représentent quatre types d'appareils de conodontes, qui diffèrent les uns des autres par la morphologie des éléments P1. Malgré une morphologie apparemment différente, tous les conodontes étudiés possèdent des valeurs proches de $\delta 13 \mathrm{C}_{\mathrm{org}}$. Le contrôle taxonomique de la composition en isotopes de carbone est également insuffisant. La forte cohérence de la composition en isotopes du carbone de la matière organique des conodontes suggère que les conodontes du Dévonien supérieur et du Carbonifère (Mississippian) occupaient des niveaux trophiques similaires. Des valeurs assez faibles de $\delta^{13} \mathrm{C}_{\text {org }}$ dans la matière organique des conodontes permettent de supposer que les conodontes sont de faibles consommateurs, probablement de seston et de plancton. 


\section{INTRODUCTION}

Conodonts were the Cambrian-Triassic extinct group of the small free-swimming, probably nektonic, marine animals having debated affinities (e.g. Donoghue et al. 2000; Blieck et al. 2010; Turner et al. 2010). The only mineralized parts of conodonts are fifteen or nineteen tooth-like elements arranged in a bilaterally subsymmetrical apparatus. Conodont elements are composed of protein-apatite nanocomposites, which form highly mineralized tissues (Trotter \& Eggins 2006; Rosseeva et al. 2011). Previous investigations demonstrated that mineral component of conodont elements is represented by apatite- $(\mathrm{CaF})$ and organic matter, consisting of less than 3 wt. $\%$ of a conodont element, composed of collagen-like protein (e.g. Kemp 2002; Rosseeva et al. 2011; Zhuravlev 2017; Medici et al. 2019). The protein network is surrounded by aligned crystallites of apatite and strongly incorporated into the mineral matrix. This incorporation provides unique conservation of the organic matter demonstrating preserved supramolecular protein structure (Zhuravlev 2017). Recrystallization of the bioapatite starts at $300^{\circ} \mathrm{C}(\mathrm{Li}$ et al. 2015). Thus changes in mineral component of conodont elements are expected at Conodont Alteration Index $(\mathrm{CAI})>5$. Collagen thermal denaturation starts at $60-65^{\circ} \mathrm{C}$ in hydrated condition and at $150^{\circ} \mathrm{C}$ in dry environment (Bozec \& Odlyha 2011), that promises good preservation of conodont organic components at $\mathrm{CAI}<3$.

Low content of carbonate ions in conodont apatite of lamellar, paralamellar, and albid tissues (less than 1.5\% according to Trotter \& Eggins 2006; Frank-Kamenetskaya et al. 2014) makes it possible to study of carbon isotope values of organic matter in conodont elements without their demineralization (Zhuravlev \& Smoleva 2018).

The isotope composition of conodont organic matter is hardly known. Over \& Grossman (1992) reported $\delta{ }^{13} C_{\text {org }}$ in conodont elements of the Late Devonian Palmatolepis Ulrich \& Bassler, 1926 (value ranges from $-24.5 \%$ to $-24.0 \%$ ), Mississippian Siphonodella Branson \& Mehl, 1944 (-26.3\%o and $-27.3 \%$ ), and Pennsylvanian Streptognathodus elegantulus Stauffer \& Plummer, 1932 (value ranges from $-23.0 \%$ to $-24.0 \%$ ). These authors noted that significant isotopic differences may be related to "local changes in source of organic carbon, global changes in the carbon budget, or to dietary differences among conodont animals" (Over \& Grossman 1992). Trophical aspect of the Late Viséan (Mississippian) conodont $\delta 13 \mathrm{C}_{\text {org }}$ values was considered by Nicholas et al. (2004). Study of $\delta^{13} C_{\text {org }}$ values of the latest Devonian and Mississippian (Tournaisian) conodont species Polygnathus parapetus Druce, 1969 revealed significant intraspecific variations probably attributed to changes in global carbon cycle and local fluctuations in source of organic matter (Zhuravlev \& Smoleva 2018). Analysis of composition of organic matter, apatite matrix, and organic carbon isotope values of the Late Devonian and Mississippian conodonts based on the limited material (13 samples) demonstrates that studied conodont elements are characterized by quite high $\mathrm{Sr} /$ Ca values in the albid tissue (from 0.002 up to 0.016 ) and low $\delta^{13} \mathrm{C}_{\text {org }}$ values in the collagen-like protein (from -30.4 up to $-22.5 \%$ ) (Zhuravlev et al. 2020). These data suggest low trophic level of studied conodonts. Also this conclusion was supported by study of $\mathrm{Ca}$ isotopes in the apatite of Late Devonian conodonts (Balter et al. 2019).

Generally, isotopic biogeochemistry of organic matter of fossil is a promising approach in reconstruction of terrestrial and aquatic paleoecosystems (Schoeninger \& DeNiro 1982, 1984; Grey 2006; Heiri et al. 2009).

The key objectives of this study are to evaluate variations in ${ }^{13} \mathrm{C}_{\text {org }}$ in conodont elements in respect to taxa, element and apparatus morphology on the basis of the extended database; to test the hypothesis about sufficient role of conodont apparatuses morphological variations in trophic differentiation of conodonts; and to reconstruct probable position of conodonts in the shallow-water trophic web.

\section{MATERIAL}

Conodont elements were studied from the Kamenka River

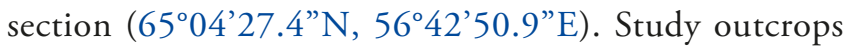
are located in the Kozhva River basin, on the banks of the Kamenka River, locating on the Pechora-Kozhva Uplift (Fig. 1). The uplift situates in the eastern part of the Pechora Plate, passive margin of the Laurussia paleocontinent. The Upper Devonian and Carboniferous are represented here by shallow-water, mainly marine siliciclastic and carbonate deposits. The terminal Famennian and lower-middle Tournaisian are represented by the Edzhid Formation comprising clayey-carbonate shallow-water deposits (Vevel' et al. 2012) (Fig. 2). About 170 limestone and clay samples collected from these deposits contain more than 2700 conodont elements, including $1440 \mathrm{P} 1$ elements that provide reliable conodont biostratigraphy. The stratigraphic interval under consideration contains abundant conodont associations composed of representatives of genera Polygnathus Hinde, 1879, shallowwater Siphonodella of the European lineage, and Hindeodus Rexroad \& Furnish, 1964. Species of Patrognathus Rhodes, Austin \& Druce, 1969, Pseudopolygnathus Branson \& Mehl, 1934, and Ligonodina Ulrich \& Bassler, 1926 occur as well. The Devonian/Carboniferous boundary is marked by the first appearance of Siphonodella sulcata (Huddle, 1934) in association with Siphonodella semichatovae Kononova \& Lipnjagov, 1976 and Patrognathus crassus Kononova \& Migdisova, 1984, that provides reliable recognition of this level (Zhuravlev 2017). The Tournaisian part of the section is correlated with standard conodont zones: from sulcata Zone through Lower crenulata Zone. The conodont associations of the study interval are dominated by the shallow-water taxa Polygnathus communis communis Branson \& Mehl, 1943, Polygnathus parapetus Druce, 1969, and Ligonodina sp.

The preservation of conodont elements is fine and they have a Conodont Alteration Index (CAI) value of 1 (i.e. $\mathrm{T}<50^{\circ} \mathrm{C}$ ). Most of the conodont elements demonstrate good preservation of histological composition proved with SEM studies and absence of traces of re-crystallysation, weathering, and 


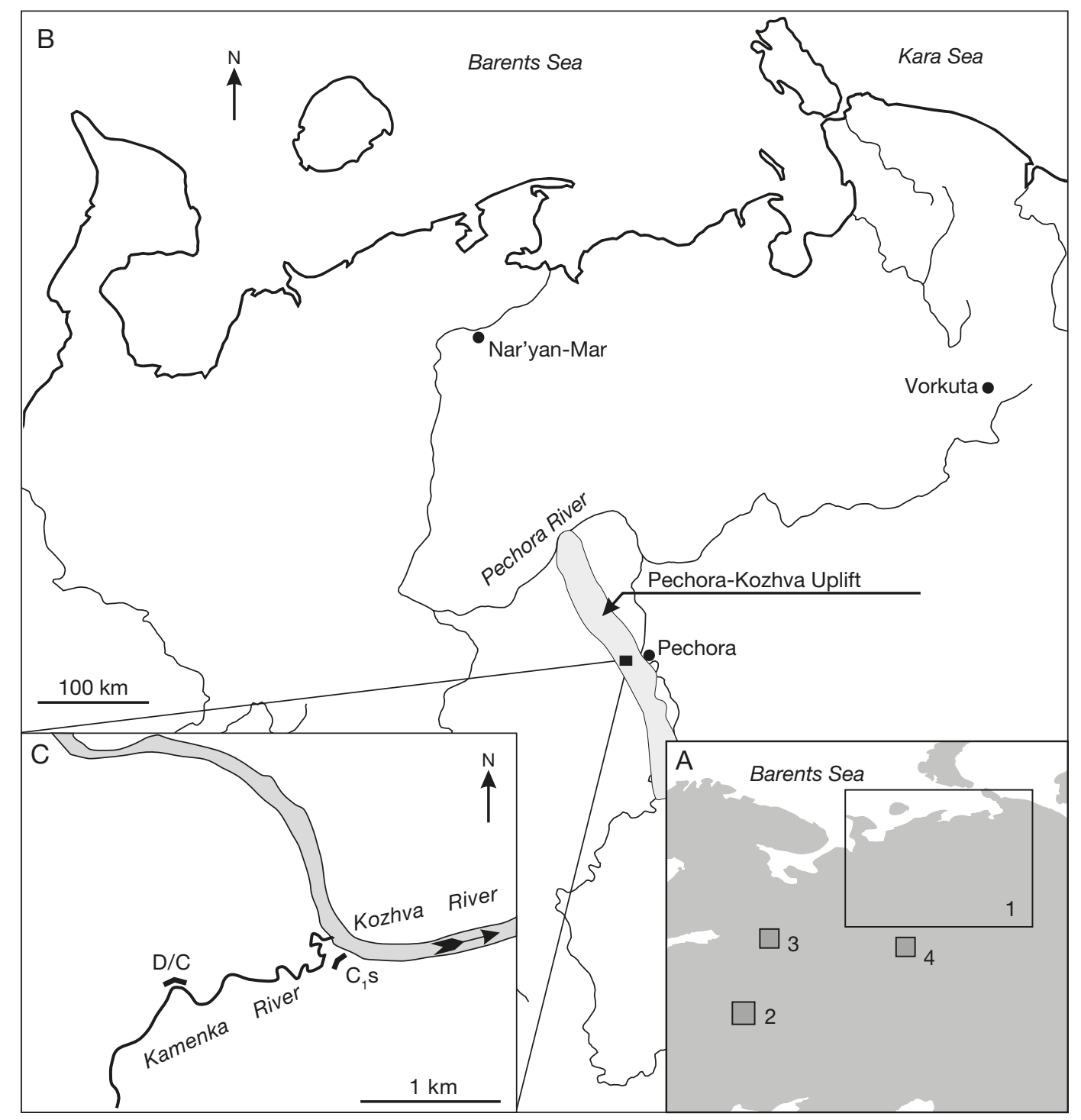

FIG. 1. - Localization of the sites under consideration: A, Generalized map of Eastern Europe; rectangles mark the localities: 1, Pechora Craton; 2, Voronezh Anteclise (Kamenka Quarry and Russkiy Brod Quarry sections); 3, Ilmen Lake region (Chudovo section, Syas River section, Ilmen Lake borehole 8, Ilmen Lake section); 4, Chimbulat Quarry. B, Map of Pechora Craton; C, Scheme of outcrops' position in the Kozhva River basin.

biodegradation (Zhuravlev \& Smoleva 2018; Zhuravlev et al. 2020). The low grade of thermal maturity suggests the preservation of the original (near-primary) carbon isotope composition of organic matter (Zhuravlev \& Smoleva 2018).

On the whole 50 conodont elements of good preservation and representing dominant taxa from the Kamenka River section were studied for $\delta 13 \mathrm{C}_{\text {org }}$ value. Additionally, $\delta 13 \mathrm{C}_{\text {org }}$ values were obtained for the Late Devonian (Early and Middle Frasnian Ligonodina, Polygnathus, Youngquistognathus Myshkina \& Zhuravlev, 2005, and Mehlina Youngquist, 1945 from the site 3 on Fig. 1A, and Early Famennian Icriodus Branson \& Mehl, 1938, Jablonnodus Dzik, 2006, and Mitrellataxis Chauff \& Price, 1980 from the site 2 on Fig. 1A), Serpukhovian (Mestognathus Bischoff, 1957 and Idioprioniodus Gunnell, 1933 from the Kamenka River section, Fig. 1C), and Middle Permian (Roadian Stepanovites from the site 4 on Fig. 1A) conodonts of the East European Platform (Fig. 1A). All the measured samples have a Conodont Alteration Index (CAI) value of 1 .

The early Famennian sections of the Voronezh Anteclise (Kamenka Quarry and Russkiy Brod Quarry sections, site 2, Fig. 1A) cropping out wavy alternation of the bluish-gray laminated clay, and gray coarse detrital wavy laminated limestone with brachiopods and bored/encrusted carbonate cobbles. The environment can be identified as a partly restricted shoreface (Zaton et al. 2014). The Frasnian of the Ilmen Lake region (Chudovo section, Syas River section, Ilmen Lake borehole 8, Ilmen Lake section, site 3, Fig. 1A) is mainly composed of alternation of the lightgray detrital limestones and greenish-gray limy clays. These deposits correspond to the shallow-water open marine and shoal environments (Zhuravlev et al. 2006). The Roadian 


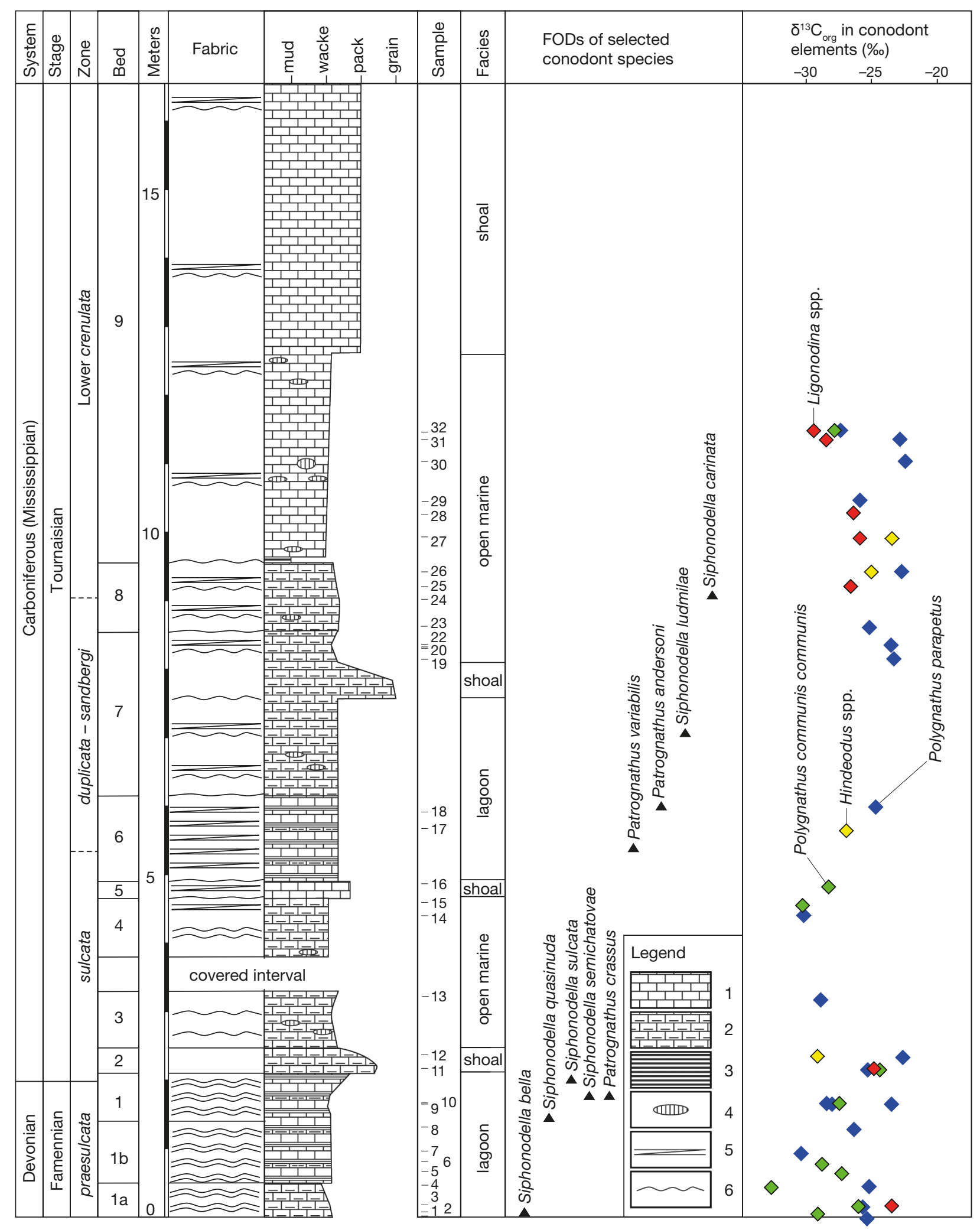

FIG. 2. - Lithology, biostratigraphy, and facies distribution of the Kamenka River section (Pechora Craton). Legend: 1, limestone; 2, clayey limestone; $\mathbf{3}$, clay; $\mathbf{4}$, cherty nodules; 5, flat lamination; 6 , wavy lamination.

(lower Kazanian in the regional nomenclature) exposed in the Chimbulat Quarry (site 4, Fig. 1A) is represented by light-gray limestones with algal-bryozoan bioherms of the shallow-water carbonate platform environment (Zhuravlev 2005). Thus all the studied localities represent shallow-water marine environments of various ages. 


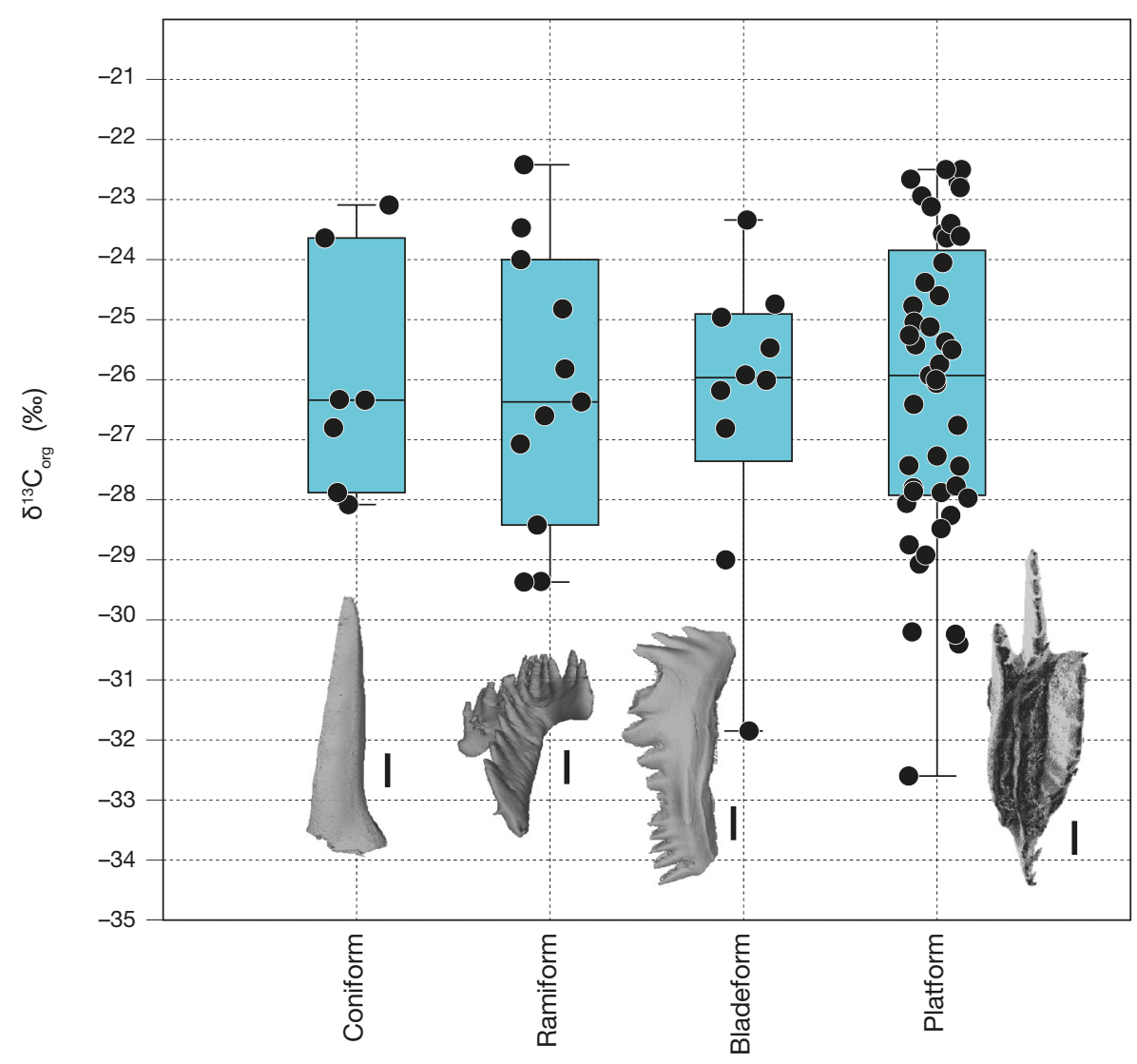

Morphology of $\mathrm{P} 1$ elements

FIG. 3. - Distribution of $\delta^{13} C_{\text {org }}$ values among conodonts having different morphological types of P1 elements. Scale bar: $0.1 \mathrm{~mm}$.

Totally $\delta 13 \mathrm{C}_{\text {org }}$ values were measured of 75 specimens, which are distributed as follows: Ligonodina, $\mathrm{n}=9$; Polygnathus, $\mathrm{n}=38$; Youngquistognathus, $\mathrm{n}=2$; Mehlina, $\mathrm{n}=3$; Icriodus, $\mathrm{n}=3$; Jablonnodus, $\mathrm{n}=4$; Mitrellataxis, $\mathrm{n}=3$; Patrognathus, $\mathrm{n}=2$; Hindeodus, $\mathrm{n}=5$; shallow-water representatives of Siphonodella, $\mathrm{n}=3$; Mestognathus, $\mathrm{n}=1$; Idioprioniodus, $\mathrm{n}=1$; Stepanovites, $\mathrm{n}=1$ (see Appendix 1).

Most of the taxa belong to so-named shallow-water biofacies and dwelt the near-shore shallow-water environment (Sandberg \& Gutschick 1984; Savoy et al. 1999). Ligonodina, Polygnathus communis, Hindeodus, Meblina, and Idioprioniodus probably occupied upper part of the water column and their remains distributed over the wide facies range (Sandberg \& Gutschick 1984; Zhuravlev \& Tolmacheva 1995; Savoy et al. 1999; Zhuravlev et al. 2006). Palaeoecology of Jablonnodus, Mitrellataxis, and Stepanovites is unclear.

\section{METHODS}

The processing of conodont samples followed the standard procedure: dissolution of limestone in $10 \%$ buffered acetic acid. The residues were washed through a sieve of $70 \mu \mathrm{m}$, dried, and conodont elements were picked out. Some elements polluted with crystals of carbonates were treated with $1 \mathrm{~N}$ solution of $\mathrm{HCl}$. Then the conodont elements were washed in ethanol and distilled water. Control of conodont element preservation was performed with optic microscopy and SEM (see Zhuravlev \& Smoleva 2018 for details).

Selected conodont elements of good preservation were used for analysis of carbon isotope values with the DELTA V Advantage mass spectrometer equipped with the Thermo Electron Continuous Flow Interface (ConFlo III) and Element Analyzer (Flash EA 1112). The $\delta{ }^{13} \mathrm{C}_{\text {org }}$ values are reported relative to the PDB standard. The international standard USGS-40 (L-Glutamic acid) was used. The analytical reproducibility $(1 \sigma)$ for $\delta^{13} \mathrm{C}_{\text {org }}$ value is $\pm 0.15 \%$.

$\delta 13 \mathrm{C}_{\text {carb }}$ values in the same carbonate samples were studied as well. Carbonate powder was drilled from the samples with steel micro-drill. The isotope studies of the powder were performed with DELTA V Advantage mass spectrometer equipped with Element Analyzer (Flash EA 1112). $\delta 13 \mathrm{C}_{\text {carb }}$ values were reported relative to the $\mathrm{PDB}$ standard. The precision of the $\delta 13 \mathrm{C}_{\text {carb }}$ value is $\pm 0.04 \%$.

Isotope analyzes were performed at the CKP 'Geonauka' of the Institute of Geology Komi SC UrB RAS (Syktyvkar, Russia). 


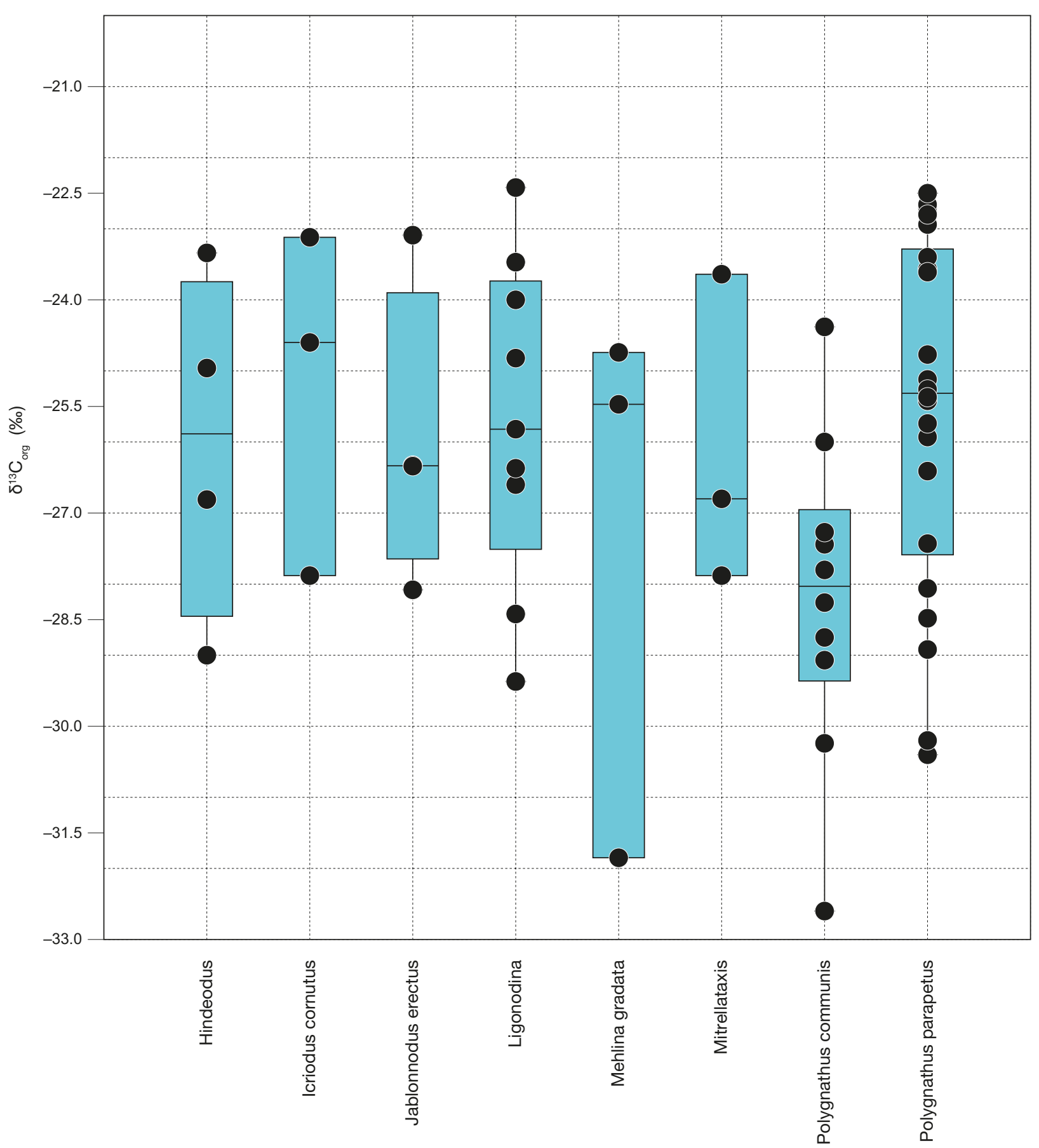

FIG. 4. - Organic carbon isotope compositions of conodonts measured in the study.

\section{RESULTS}

Carbon isotope composition was studied in 75 samples (Figs 3 , 4). The results of the isotopic investigation of organic matter of the conodont elements are summarized in the Appendix 1. ${ }^{13} \mathrm{C}_{\text {org }}$ values of conodont elements measured in this study range from $-32.6 \%$ to $-22.1 \%$, with an average value of $-26.0 \pm 4.8 \%$ o ( \pm 2 s.d., $\mathrm{n}=75$ ). The average $\delta^{13} \mathrm{C}_{\text {org }}$ value is $-26.2 \pm 4.9 \%$ o $( \pm 2$ s.d., $\mathrm{n}=49)$ at the terminal Famennian - Tournaisian of the Kamenka River section, $-25.4 \%$ o $\pm 5.4 \%$ o ( \pm 2 s.d., $\mathrm{n}=12)$ at the Frasnian of the Ilmen Lake region (East European Platform), $-25.8 \%$ \% \pm .0\%o $( \pm 2$ s.d., $\mathrm{n}=10)$ at the lower Famennian of the Kamenka Quarry and Russkiy Brod Quarry (Voronezh Anteclise, East European Platform).

The study taxa represent four types of conodont apparatus, which differ one from another by morphology of P1 elements (Zhuravlev 2007). The types are the following: 1) apparatus composed of coniform elements only (genera Mitrellataxis and Jablonnodus); 2) apparatus characterized 
Sea level

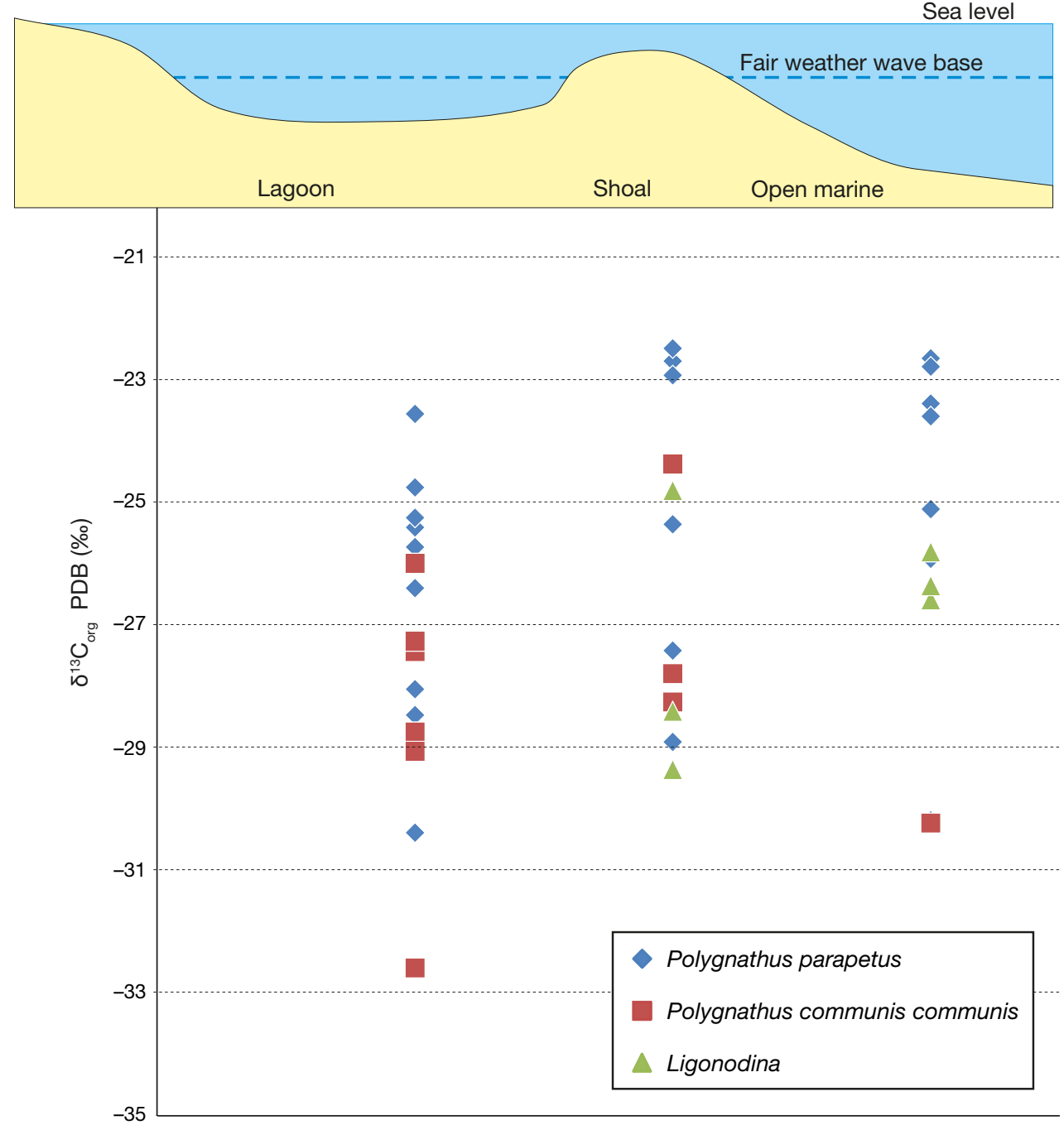

FIG. 5. $-\delta^{13} \mathrm{C}_{\text {org }}$ distribution along the facies profile plotted for dominating taxa (latest Famennian-middle Tournaisian; Kamenka River section).

by ramiform elements in $\mathrm{P}$ position (genera Ligonodina, Idioprioniodus, Stepanovites); 3) apparatus having bladeform elements in P1 position (genera Mehlina and Hindeodus); and 4) apparatus demonstrating platform elements in P1 position (genera Icriodus, Polygnathus, Youngquistognathus, Siphonodella, Mestognathus). Specimens grouped on the basis of morphological types of apparatus demonstrate close $\delta 13 \mathrm{C}_{\text {org }}$ values without statistically significant differences (Fig. 3). The average $\delta 13 \mathrm{C}_{\text {org }}$ values are distributed as following: $-26.0 \pm 3.9 \%$ ( \pm 2 s.d., $n=7$ ) for the first type; $-26.2 \pm 4.7 \%$ o ( \pm 2 s.d., $\mathrm{n}=11$ ) for the second type; -26.4 $\pm 4.8 \%$ ( \pm 2 s.d., $\mathrm{n}=10$ ) for the third type; and $-26.1 \pm$ $5.0 \%$ ( \pm 2 s.d., $n=45)$ for the fourth type. Thus in spite of apparently different morphology all the studied conodonts possess close $\delta 13 \mathrm{C}_{\text {org }}$ values.

Comparisons between conodonts grouped by species reveal no taxonomic difference in $\delta 13 \mathrm{C}_{\text {org }}$ value, excluding the Famennian-Tournaisian ubiquitic species Polygnathus communis communis Branson \& Mehl (Fig. 4). This species, having platform P1 elements of simple morphology, demonstrates low $\delta 13 \mathrm{C}_{\text {org }}$ values (mean value is $-28.2 \%$ ).
The other species under consideration reveal similar $\delta{ }^{13} \mathrm{C}_{\text {org }}$ values. For example, the average $\delta 13 \mathrm{C}_{\text {org }}$ value of Polygnathus parapetus Druce is $-25.5 \pm 1.1 \%$ o $( \pm 2$ s.d., $\mathrm{n}=22)$, and the average $\delta 13 \mathrm{C}_{\text {org }}$ value of Ligonodina sp. is $-25.7 \pm 1.5 \%$ o $( \pm 2$ s.d., $\mathrm{n}=9$ ). At the order level the average $\delta{ }^{13} \mathrm{C}_{\text {org }}$ values are indistinguishable as well. Representatives of the order Ozarkodinida Dzik, 1976 comprising genera Polygnathus, Youngquistognathus, Siphonodella, Hindeodus, and Mehlina show the average $\delta^{13} \mathrm{C}_{\text {org }}$ value of $-26.2 \pm 4.9 \%$ ( \pm 2 s.d., $n$ =52). Representatives of another order Prioniodinida Sweet, 1988 (genera Ligonodina, Stepanovites, and Idiorioniodus) demonstrates the same average value of $-26.2 \pm 4.7 \%$ o $( \pm 2$ s.d., $\mathrm{n}=11)$. Thus there is no evident taxonomic control on the $\delta 13 \mathrm{C}_{\text {org }}$ values in conodont organic matter in the studied material.

The material obtained allows evaluating facies control on the $\delta 13 \mathrm{C}_{\text {org }}$ values in conodont elements of the three Famennian-Tournaisian taxa: Polygnathus parapetus, Polygnathus communis communis, and Ligonodina sp. $\delta 13 \mathrm{C}_{\mathrm{org}}$ values in conodont elements of all the species show high consistency through facies gradient (Fig. 5). 


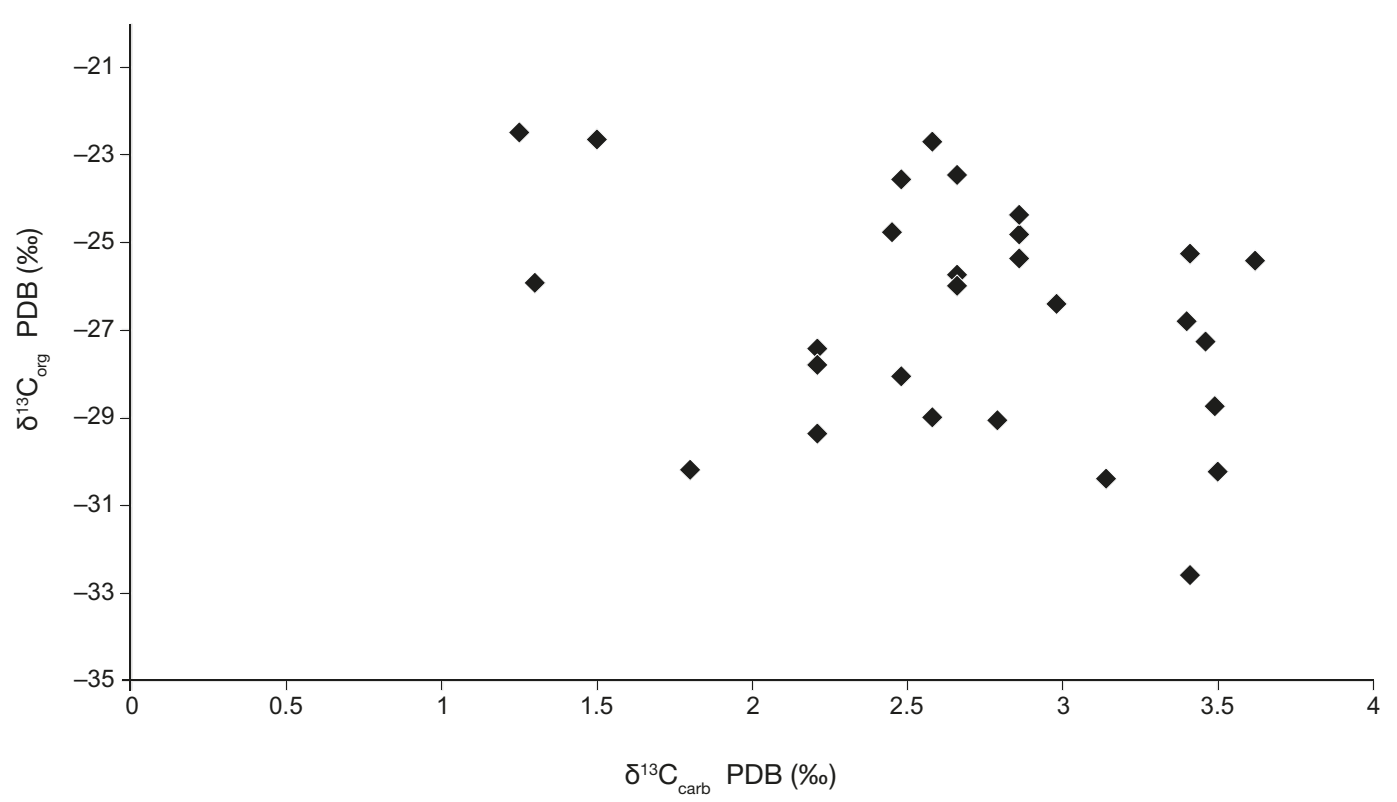

FIG. 6. - Bivariate plot for bulk carbonate $\delta^{13} C_{\text {carb }}$ and conodont $\delta^{13} C_{\text {org }}$ values.

\section{DISCUSSION}

Low grade of thermal maturity of the studied specimens $(\mathrm{CAI}<2)$ promises weak degree of degradation of conodont organic matter and good preservation of conodont ${ }^{13} \mathrm{C}_{\text {org }}$ signatures (Zhuravlev $\&$ Smoleva 2018). For studied specimens no traces of microbial activity were detected that promises low level of isotope exchange between the conodont elements and water or sediment (Zazzo et al. 2004). Also no signs of conodont element re-crystallisation were observed. Another line of evidence of primary nature of conodont $\delta^{13}$ Corg is based on discordant variations of $\delta^{13} \mathrm{C}$ values in conodont elements and host carbonates (Zhuravlev \& Smoleva 2018) (Fig. 6). Just weak negative trend is observed, which can be caused by influence of the primary productivity recorded in $\delta 13 \mathrm{C}_{\text {carb }}$ on trophic peculiarities of conodonts reflected by $\delta^{13} \mathrm{C}_{\text {org }}$. Taking into account high resistance of the conodont mineralized tissues against degradational factors (Zhuravlev 2017; Zhuravlev \& Shevchuk 2017; Zhuravlev \& Smoleva 2018) it can be supposed that material under consideration reveals near-primary isotope composition of the organic matter.

${ }^{13} \mathrm{C}$ value in consumer tissues is being used as tools in assigning trophic status, because of the carbon isotope ratio of an organism closely reflects the carbon isotope ratio of its food (Schoeninger \& DeNiro 1984). The mean value of $\delta^{13} \mathrm{C}_{\text {org }}$ of conodont organic matter is quite low and corresponds to that of recent zooplankton and other low-level consumers (Bohata \& Koppelmann 2013), but far from $\delta 13 \mathrm{C}_{\text {org }}$ values of high-level consumers, e.g. marine vertebrates (from $-14 \%$ o up to $-10 \%$ ) (Schoeninger \& DeNiro, 1984). Thus it is possible to suppose that studied conodonts were low-level consumers. This conclusion is compatible with data on Ca isotopes interpreted as sign of low trophic level of the Late Devonian conodonts (Balter et al. 2019), and with information on rather high $\mathrm{Sr} / \mathrm{Ca}$ ratio in conodont bioapatite (Zhuravlev et al. 2020).
Surprising high consistency of $\delta 13 \mathrm{C}_{\text {org }}$ values of conodonts belonging to different taxa and morphological groups supports weak trophic differentiation among conodonts (Figs. 3, 4). At least, the Late Devonian-Mississipian shallow-water conodonts probably occupied similar trophic levels corresponding to seston and phytoplankton feeders (see also Zhuravlev \& Smoleva 2018). The morphological differences in conodont apparatuses and elements were perhaps responsible to the fine trophic specialization only. Thus the hypothesis about sufficient role of conodont apparatuses morphological variations in trophic differentiation of conodonts (e.g. Purnell 1995; Purnell \& Donoghue 1997; Zhuravlev 2007; Purnell \& Jones $2012)$ is not confirmed by the isotopic data.

Moreover the temporal variations in average $\delta^{13} \mathrm{C}_{\text {org }}$ values observed in the Late Devonian-Mississippian interval are of low amplitude. The range of these variations is about $1 \%$ that suggests rather statistically insignificant stratigraphic trend. It seems that trophical position of the shallow-water conodonts remained unchanged over the long time.

Rather low trophic level of the middle Palaeozoic conodonts is also supported by signs of predation of fishes (cladoselachian sharks, coelacanth, palaeoniscoid and actinopterygian fishes) on conodonts (Nicoll 1977; Choo et al. 2009; Zatoń \& Rakociński 2014; Zatoń et al. 2017). These data suggest that conodonts occupied trophic levels below of those of fishes.

\section{CONCLUSIONS}

An isotopic investigation of organic matter of the Late Devonian-Mississippian conodont elements of various morphology and taxonomic position demonstrate weak variations in $\delta^{13} \mathrm{C}_{\mathrm{org}}$ values. High consistency of the carbon isotope composition of conodont organic matter suggests that the Late Devonian and Mississippian conodonts occupied similar trophic levels 
despite of different morphology and apparatus composition. Quite low $\delta 13 \mathrm{C}_{\text {org }}$ values in conodont organic matter $(-26.0 \pm$ $4.8 \%$ ) allow supposing that conodonts were low level consumers, probably seston and phytoplankton feeders. Results obtained promise approach to reconstructing of the trophic structure of the Palaeozoic pelagic ecosystems, where conodonts were one of the most abundant and diverse group of animals.

\section{Acknowledgements}

Author thanks two anonymous reviewers for their insightful comments. Author would like to thank Irina Smoleva for help in the isotope study. Isotope analyzes were performed at the CKP "Geonauka” of Institute of Geology Komi SC UrB RAS (Syktyvkar, Russia).

\section{REFERENCES}

Balter V., Martin J. E., Tacail T., Suan G., Renaud S. \& Girard C. 2019. - Calcium stable isotopes place Devonian conodonts as first level consumers. Geochemical Perspectives. Letters 10: 36-39. https://doi.org/10.7185/geochemlet.1912

Blieck A., Turner S., Burrow C. J., Schultze H.-P., Rexroad C. B., Bultynck P. \& Nowlan G. S. 2010. — Fossils, histology, and phylogeny: why conodonts are not vertebrates. Episodes 33: 234-241. https://doi.org/10.18814/epiiugs/2010/v33i4/002

BoHAtA K. \& KoppelmanN R. 2013. - Chaetognatha of the Namibian Upwelling Region: Taxonomy, Distribution and Trophic Position. PLoS ONE 8(1): e53839. https://doi.org/10.1371/ journal.pone.0053839

Bozec L. \& OdlyHa M. 2011. — Thermal Denaturation Studies of Collagen by Microthermal Analysis and Atomic Force Microscopy. Biophysical Journal 101: 228-236. https://doi.org/10.1016/j. bpj.2011.04.033

Choo B., Long J. A. \& Trinajstic K. 2009. - A new genus and species of basal actinopterygian fish from the Upper Devonian Gogo Formation of Western Australia. Acta Zoologica 90: 194210. https://doi.org/10.1111/j.1463-6395.2008.00370.x

Donoghue P. C. J., Forey P. L. \& Aldridge R. J. 2000. Conodont affinity and chordate phylogeny. Biological Reviews 75 191-251. https://doi.org/10.1111/j.1469-185X.1999.tb00045.x

FRANK-KAMENETSKAYA O. V., ROZHDESTVENSKAYA I. V., RosSEEVA E. V. \& Zhuravlev A. V. 2014. - Refinement of Apatite Atomic Structure of Albid Tissue of Late Devon Conodont. Crystallography Reports 59 (1): 41-47. https://doi.org/10.1134/ S1063774514010039

GREY J. 2006. - The use of stable isotope analyses in freshwater ecology: Current awareness. Polish Journal of Ecology 54: 563-584.

Heiri O., Wooller M. J., van Hardenbroek M. \& Wang Y. V. 2009. - Stable isotopes in chitinous fossils of aquatic invertebrates. PAGES News 17 (3): 100-102. https://doi.org/10.22498/ pages.17.3.100

KeMP A. 2002. - Amino acid residues in conodont elements. Journal of Paleontology 76 (3): 518-528. https://doi.org/10.1017/ S0022336000037343

LI Z., WU S. \& YE C. 2015. - Temperature-related changes of bioapatite based on hypermineralized dolphin's bulla. Journal of Raman Spectroscopy 46: 964-968. https://doi.org/10.1002/jrs.4653

Medici L., Malferrari D., Savioli M. \& Ferretti F. 2019. Mineralogy and crystallization patterns in conodont bioapatite from first occurrence (Cambrian) to extinction (end-Triassic). Palaeogeography, Palaeoclimatology, Palaeoecology 549: 109098. https://doi.org/10.1016/j.palaeo.2019.02.024
Nicholas C., Murray J., Goodhue R. \& Ditchfield P. 2004. Nitrogen and carbon isotopes in conodonts: Evidence of trophic levels and nutrient flux in Palaeozoic oceans. The Palaeontological Association 48th Annual Meeting, 17th-20th December 2004 , University of Lille, Abstracts: 126, 127.

NiCOLL R. S. 1977. - Conodont apparatuses in an Upper Devonian palaeoniscoid fish from the Canning Basin, Western Australia. BMR Journal of Australian Geology \& Geophysics 2: 217-228. http://pid.geoscience.gov.au/dataset/ga/80929

Over D. J. \& Grossman E. L. 1992. - Carbon isotope analysis of conodont organic material - procedure and preliminary results. Geological Society of America, Abstracts with Programs 24: A214.

PuRNELl M. A. 1995. - Microwear on conodont elements and macrophagy in the first vertebrates. Nature 374: 798-800. https:// doi.org/10.1038/374798a0

Purnell M. A. \& Donoghue P. C. J. 1997. - Architecture and functional morphology of the skeletal apparatus of ozarkodinid conodonts. Philosophical Transactions of the Royal Society of London B 352: 1545-1564. https://doi.org/10.1098/rstb.1997.0141

PuRnell M. A. \& JONES D. 2012. - Quantitative analysis of conodont tooth wear and damage as a test of ecological and functional hypotheses. Paleobiology 38: 605-626. https://doi. org/10.1666/09070.1

Rosseeva E., Borrmann H., Cardoso-Gil R., Carrillo-Cabrera W., Frank-Kamenetskaya O. V., ÖZtan Y., Prots Y., SChWarZ U., Simon P., Zhuravlev A. V. \& Kniep R. 2011. — Evolution and complexity of dental (apatite-based) biominerals: Mimicking the very beginning in the laboratory. Max-Planck-Institut für Chemische Physik fester Stoffe, Scientific Report 2009-2010: 171-176.

SANDBERG C. A. \& GUTSCHICK R. C. 1984. — Distribution, microfauna and source-rock potential of Mississippian Delle Phosphatic Member of Woodman Formation and equivalents, Utah and adjacent States, in WoOdWard J., MEISSNER F. F. \& ClaYTON J. L. (eds), Hydrocarbon Source Rocks of the Greater Rocky Mountain Region. Rocky Mountain Association of Geologists: 135-178.

SavoY L. E., Harris A. G. \& MounTJOY E. W. 1999. — Extension of lithofacies and conodont biofacies models of Late Devonian to Early Carboniferous carbonate ramp and black shale systems, southern Canadian Rocky Mountains. Canadian Journal of Earth Sciences 36 (8): 1281-1298. https://doi.org/10.1139/e99-037

SChoeninger M. J. \& DeNiro M. J. 1982. — Carbon isotopes ratios of apatite from fossil bone cannot be used to reconstruct diets of animals. Nature 297: 577-578. https://doi.org/10.1038/297577a0

Schoeninger M. J. \& DeNiro M. J. 1984. — Nitrogen and carbon isotopic composition of bone collagen from marine and terrestrial animals. Geochimica et Cosmochimica Acta 48: 625-639. https:// doi.org/10.1016/0016-7037(84)90091-7

TrotTer J. A. \& EgGins S. M. 2006. - Chemical systematics of conodont apatite determined by laser ablation ICPMS. Chemical Geology 233: 196-216. https://doi.org/10.1016/j. chemgeo.2006.03.004

Turner S., Burrow C. J., SChultze H.-P., Blieck A., ReiF W.-E., Rexroad C. B., Bultynck P. \& Nowlan G. S. 2010. — False teeth: conodont-vertebrate phylogenetic relationships revisited. Geodiversitas 32 (4): 545-594. https://doi.org/10.5252/g2010n4a1

Vevel' Y. A., Zhuravlev A. V. \& Popov V. V. 2012. - Deposits of the Devonian and Carboniferous boundary in the Kamenka River section (Pechora-Kozhvinsky megaswell, Timan-Pechora province). Neftegazovaa geologia. Teoria i practika (RUS) 7 (1) (in Russian, English abstract).

Zatoń M., Broda K., Qvarnström M., NiedźWIEDZKi G. \& AhlberG P. E. 2017. - The first direct evidence of a Late Devonian coelacanth fish feeding on conodont animals. Science of Nature 104, 26. https://doi.org/10.1007/s00114-017-1455-7

ZATOŃ M. \& RAKOCIŃSKI M. 2014. - Coprolite evidence for carnivorous predation in a Late Devonian pelagic environment of southern Laurussia. Palaeogeography, Palaeoclimatology, Palaeoecology 394: 1-11. https://doi.org/10.1016/j.palaeo.2013.11.019 
Zatón M., Zhuravlev A. V., Rakociński M., Filipiak P., BORSZCZ T., KRAWCZYŃSKI W., Wilson M. A. \& SOKIRAN E. V. 2014. - Microconchid-dominated cobbles from the Upper Devonian of Russia: opportunism and dominance in a restricted environment following the Frasnian-Famennian biotic crisis. Palaeogeography, Palaeoclimatology, Palaeoecology 401: 142-153. https://doi.org/10.1016/j.palaeo.2014.02.029

ZAZZO A., LÉCUYER C. \& MARIOTTI A. 2004. - Experimentallycontrolled carbon and oxygen isotope exchange between bioapatites and water under inorganic and microbially-mediated conditions. Geochimica et Cosmochimica Acta 68: 1-12. https:// doi.org/10.1016/s0016-7037(03)00278-3

ZhuravleV A. V. 2005. - Conodont associations of the Nemda Formation (Kazanian Stage, Volga-Vyatka area). Regional Geology and Metallogeny 23: 69-73 (in Russian).

Zhuravlev A. V. 2007. - Morphofunctional Analysis of Late Paleozoic Conodont Elements and Apparatuses. Paleontological Journal 41 (5): 549-557. https://doi.org/10.1134/S0031030107050103

ZHURAVLEV A. V. 2017. - Structure of the organic matter of conodont elements: Atomic Force Microscopy data. Vestnik IG Komi SC UB RAS 10: 20-25 (in Russian, English summary). https:// doi.org/10.19110/2221-1381-2017-10-20-25

Zhuravlev A. V., Plotitsyn A. N. \& GruZdev D. A. 2020. Carbon Isotope Ratios in the Apatite-Protein Composites of
Conodont Elements - Palaeobiological Proxy. Lecture Notes in Earth System Sciences, in FranK-KaMENETSKAYA O. V., Vlasov D. Y., Panova E. G., Lessovaia S. N. (eds), Processes and Phenomena on the Boundary between Biogenic and Abiogenic Nature. Springer, Cham: 749-764. https://doi.org/10.1007/978-3-03021614-6_40

Zhuravlev A. V. \& SheVchuk S. S. 2017. - Strontium distribution in Upper Devonian conodont elements: a palaeobiological proxy. Rivista Italiana di Paleontologia e Stratigrafia 123 (2): 203210. https://doi.org/10.13130/2039-4942/8311

Zhuravlev A. V. \& Smoleva I. V. 2018. - Carbon isotope values in conodont elements from the latest Devonian - Early Carboniferous carbonate platform facies (Timan-Pechora Basin). Estonian Journal of Earth Sciences 67 (4): 238-246. https://doi. org/10.3176/earth.2018.17

Zhuravlev A. V., Sokiran E. V., Evdokimova I. O., Dorofeeva L. A., Rusetskaya G. A., \& MaŁKOwski K. 2006. - Faunal and facies changes at the Early-Middle Frasnian boundary in the north-western East European Platform. Acta Palaeontologica Polonica 51 (4): 747-758

Zhuravlev A. V. \& TolmacheVA T. J. 1995. - Ecological recovery of conodont communities after Cambrian/Ordovician and Devonian/Carboniferous events. CFS Courier Forschungsinstitut Senckenberg 182: 313-324.

\begin{tabular}{|c|c|c|c|c|}
\hline Section and age & Sample & Taxon & $\begin{array}{l}\delta^{13} C_{\text {org }} \text { PDB } \\
\% \text { o }\end{array}$ & $\begin{array}{l}\delta^{13} \mathrm{C}_{\text {carb }} \text { PDB } \\
\% \\
\text { (host rock) }\end{array}$ \\
\hline Chimbulat Quarry, $\mathrm{P}_{2}$ rd & Chm-3/04 & Stepanovites & -29.36 & $\mathrm{n} / \mathrm{a}$ \\
\hline $\begin{array}{l}\text { Chudovo section, } D_{3} f \\
\text { Chudovo section, } D_{3} f\end{array}$ & $\begin{array}{l}\mathrm{CH} 1-6 / 97 \\
\mathrm{CH} 1-6 / 97\end{array}$ & $\begin{array}{l}\text { Mehlina gradata } \\
\text { Polygnathus reimersi }\end{array}$ & $\begin{array}{l}-25.47 \\
-25.04\end{array}$ & $\begin{array}{l}\mathrm{n} / \mathrm{a} \\
\mathrm{n} / \mathrm{a}\end{array}$ \\
\hline $\begin{array}{l}\text { Ilmen Lake, borehole } 8, D_{3} f \\
\text { Ilmen Lake, borehole } 8, D_{3} f \\
\end{array}$ & $\begin{array}{l}8 / 50 P \\
8 / 50 P\end{array}$ & $\begin{array}{l}\text { Polygnathus reimersi } \\
\text { Mehlina gradata }\end{array}$ & $\begin{array}{l}-22.5 \\
-24.74\end{array}$ & $\begin{array}{l}\mathrm{n} / \mathrm{a} \\
\mathrm{n} / \mathrm{a}\end{array}$ \\
\hline $\begin{array}{l}\text { Ilmen Lake, } D_{3} f \\
\text { Ilmen Lake, } D_{3} f \\
\text { IImen Lake, } D_{3} f \\
\text { Ilmen Lake, } D_{3} f \\
\text { Ilmen Lake, } D_{3} f \\
\text { Ilmen Lake, } D_{3} f \\
\text { Ilmen Lake, } D_{3} f \\
\text { IImen Lake, } D_{3} f \\
\end{array}$ & $\begin{array}{l}1314 / 3 \\
5102 / 4 \\
5102 a-2 \\
5103 / 10 \\
5130 / 3-2 \\
5132 / 0 \\
F-2-0 \\
F-2-0 \\
\end{array}$ & $\begin{array}{l}\text { Ligonodina sp. } \\
\text { Polygnathus webbi } \\
\text { Youngquistognathus sp. } \\
\text { Polygnathus efimovae } \\
\text { Ligonodina sp. } \\
\text { Mehlina gradata } \\
\text { Polygnathus ilmenensis } \\
\text { Polygnathus efimovae }\end{array}$ & $\begin{array}{l}-22.42 \\
-23.64 \\
-24.05 \\
-22.08 \\
-24 \\
-31.85 \\
-27.77 \\
-27.86 \\
\end{array}$ & $\begin{array}{r}\mathrm{n} / \mathrm{a} \\
\mathrm{n} / \mathrm{a} \\
-3.86 \\
\mathrm{n} / \mathrm{a} \\
\mathrm{n} / \mathrm{a} \\
\mathrm{n} / \mathrm{a} \\
\mathrm{n} / \mathrm{a} \\
\mathrm{n} / \mathrm{a}\end{array}$ \\
\hline $\begin{array}{l}\text { Kamenka Quarry, } D_{3} \mathrm{fm}_{1} \\
\text { Kamenka Quarry, } \mathrm{D}_{3} \mathrm{fm}_{1}\end{array}$ & $\begin{array}{l}\mathrm{D} 04-5 / 12 \\
\mathrm{D} 04-6 / 12\end{array}$ & $\begin{array}{l}\text { Icriodus cornutus } \\
\text { Icriodus cornutus }\end{array}$ & $\begin{array}{l}-24.6 \\
-27.88\end{array}$ & $\begin{array}{l}\mathrm{n} / \mathrm{a} \\
\mathrm{n} / \mathrm{a}\end{array}$ \\
\hline $\begin{array}{l}\text { Kamenka River section, } \mathrm{C}_{1} \mathrm{~s} \\
\text { Kamenka River section, } \mathrm{C}_{1} \mathrm{~s}\end{array}$ & $\begin{array}{l}125-1-8 / 90 \\
125-5 b / 16\end{array}$ & $\begin{array}{l}\text { Mestognathus bipluti } \\
\text { Idioprioniodus sp. }\end{array}$ & $\begin{array}{l}-25.5 \\
-27.07\end{array}$ & $\begin{array}{l}\mathrm{n} / \mathrm{a} \\
\mathrm{n} / \mathrm{a}\end{array}$ \\
\hline $\begin{array}{l}\text { Kamenka River section, } D_{3} \mathrm{fm} \\
\text { Kamenka River section, } D_{3} \mathrm{fm} \\
\text { Kamenka River section, } D_{3} \mathrm{fm} \\
\text { Kamenka River section, } D_{3} \mathrm{fm} \\
\text { Kamenka River section, } D_{3} \mathrm{fm} \\
\text { Kamenka River section, } D_{3} \mathrm{fm} \\
\text { Kamenka River section, } D_{3} \mathrm{fm} \\
\text { Kamenka River section, } D_{3} \mathrm{fm} \\
\text { Kamenka River section, } D_{3} \mathrm{fm} \\
\text { Kamenka River section, } D_{3} \mathrm{fm} \\
\text { Kamenka River section, } D_{3} \mathrm{fm}\end{array}$ & $\begin{array}{l}1 \\
2 \\
3 \\
3 \\
3 \\
4 \\
4 \\
5 \\
6 \\
7 \\
8\end{array}$ & $\begin{array}{l}\text { Polygnathus parapetus } \\
\text { Polygnathus communis communis } \\
\text { Ligonodina sp. } \\
\text { Polygnathus parapetus } \\
\text { Polygnathus communis communis } \\
\text { Polygnathus communis communis } \\
\text { Polygnathus parapetus } \\
\text { Polygnathus communis communis } \\
\text { Polygnathus communis communis } \\
\text { Polygnathus parapetus } \\
\text { Polygnathus parapetus }\end{array}$ & $\begin{array}{l}-25.42 \\
-29.07 \\
-23.47 \\
-25.74 \\
-26 \\
-32.6 \\
-25.26 \\
-27.27 \\
-28.75 \\
-30.4 \\
-26.41\end{array}$ & $\begin{array}{l}3.62 \\
2.79 \\
2.66 \\
2.66 \\
2.66 \\
3.41 \\
3.41 \\
3.46 \\
3.49 \\
3.14 \\
2.98\end{array}$ \\
\hline
\end{tabular}


APPENDIX 1. - Continuation.

\begin{tabular}{|c|c|c|c|c|}
\hline Section and age & Sample & Taxon & $\begin{array}{l}\delta^{\delta^{13} C_{\text {org }} \text { PDB }} \\
\%\end{array}$ & $\begin{array}{l}\delta^{13} C_{\text {carb }} \text { PDB } \\
\% \text { o } \\
\text { (host rock) }\end{array}$ \\
\hline Kamenka River section, $\mathrm{C}_{1}$ tn & 9 & Polygnathus parapetus & -23.57 & 2.48 \\
\hline Kamenka River section, $C_{1}$ tn & 9 & Polygnathus parapetus & -28.06 & 2.48 \\
\hline Kamenka River section, $\mathrm{C}_{1}$ tn & 10 & Polygnathus communis communis & -27.44 & $\mathrm{n} / \mathrm{a}$ \\
\hline Kamenka River section, $C_{1}$ tn & 10 & Polygnathus parapetus & -28.48 & $n / a$ \\
\hline Kamenka River section, $\mathrm{C}_{1}$ tn & 11 & Polygnathus parapetus & -25.37 & 2.86 \\
\hline Kamenka River section, $\mathrm{C}_{1}$ tn & 11 & Ligonodina sp. & -24.82 & 2.86 \\
\hline Kamenka River section, $\mathrm{C}_{1}$ tn & 11 & Polygnathus communis communis & -24.38 & 2.86 \\
\hline Kamenka River section, $C_{1}$ tn & 11 & Siphonodella bella & -22.52 & 2.86 \\
\hline Kamenka River section, $\mathrm{C}_{1}$ tn & 11 & Hindeodus crassidentatus & -24.65 & 2.86 \\
\hline Kamenka River section, $C_{1}$ tn & 12 & Polygnathus parapetus & -22.71 & 2.58 \\
\hline Kamenka River section, $\mathrm{C}_{1}$ tn & 12 & Hindeodus crassidentatus & -29 & 2.58 \\
\hline Kamenka River section, $C_{1}$ tn & 13 & Polygnathus parapetus & -28.92 & $\mathrm{n} / \mathrm{a}$ \\
\hline Kamenka River section, $\mathrm{C}_{1}$ tn & 14 & Polygnathus parapetus & -30.2 & 1.8 \\
\hline Kamenka River section, $\mathrm{C}_{1}$ tn & 15 & Polygnathus communis communis & -30.24 & 3.5 \\
\hline Kamenka River section, $\mathrm{C}_{1}$ tn & 16 & Polygnathus communis communis & -28.26 & $\mathrm{n} / \mathrm{a}$ \\
\hline Kamenka River section, $C_{1}$ tn & 17 & Hindeodus penescitulus & -26.81 & 3.4 \\
\hline Kamenka River section, $C_{1}$ tn & 18 & Polygnathus parapetus & -24.77 & 2.45 \\
\hline Kamenka River section, $C_{1}$ tn & 19 & Polygnathus parapetus & -23.4 & $\mathrm{n} / \mathrm{a}$ \\
\hline Kamenka River section, $\mathrm{C}_{1}$ tn & 20 & Patrognathus andersoni & -26.01 & $n / a$ \\
\hline Kamenka River section, $C_{1}$ tn & 21 & Patrognathus andersoni & -26.18 & $\mathrm{n} / \mathrm{a}$ \\
\hline Kamenka River section, $C_{1}$ tn & 22 & Polygnathus parapetus & -23.61 & $\mathrm{n} / \mathrm{a}$ \\
\hline Kamenka River section, $C_{1}$ tn & 23 & Polygnathus parapetus & -25.12 & $\mathrm{n} / \mathrm{a}$ \\
\hline Kamenka River section, $C_{1}$ tn & 24 & Polygnathus parapetus & -22.66 & 1.5 \\
\hline Kamenka River section, $C_{1}$ tn & 25 & Ligonodina sp. & -26.6 & $\mathrm{n} / \mathrm{a}$ \\
\hline Kamenka River section, $\mathrm{C}_{1}$ tn & 26 & Polygnathus parapetus & -22.8 & $\mathrm{n} / \mathrm{a}$ \\
\hline Kamenka River section, $C_{1}$ tn & 26 & Siphonodella carinata & -26.76 & $\mathrm{n} / \mathrm{a}$ \\
\hline Kamenka River section, $C_{1}$ tn & 26 & Hindeodus crassidentatus & -24.96 & $\mathrm{n} / \mathrm{a}$ \\
\hline Kamenka River section, $C_{1}$ tn & 27 & Ligonodina sp. & -25.82 & $\mathrm{n} / \mathrm{a}$ \\
\hline Kamenka River section, $C_{1}$ tn & 27 & Hindeodus crassidentatus & -23.34 & $\mathrm{n} / \mathrm{a}$ \\
\hline Kamenka River section, $C_{1}$ tn & 28 & Ligonodina sp. & -26.37 & $\mathrm{n} / \mathrm{a}$ \\
\hline Kamenka River section, $\mathrm{C}_{1}$ tn & 29 & Polygnathus parapetus & -25.93 & 1.3 \\
\hline Kamenka River section, $C_{1}$ tn & 30 & Polygnathus parapetus & -22.5 & 1.25 \\
\hline Kamenka River section, $C_{1}$ tn & 31 & Polygnathus parapetus & -22.94 & $\mathrm{n} / \mathrm{a}$ \\
\hline Kamenka River section, $C_{1}$ tn & 31 & Siphonodella carinata & -26.06 & $\mathrm{n} / \mathrm{a}$ \\
\hline Kamenka River section, $C_{1}$ tn & 31 & Ligonodina sp. & -28.42 & $\mathrm{n} / \mathrm{a}$ \\
\hline Kamenka River section, C1 tn & 32 & Ligonodina discreta & -29.37 & 2.21 \\
\hline Kamenka River section, $\mathrm{C}_{1}$ tn & 32 & Polygnathus parapetus & -27.43 & 2.21 \\
\hline Kamenka River section, $\mathrm{C}_{1}$ tn & 32 & Polygnathus communis communis & -27.8 & 2.21 \\
\hline Russkiy Brod Quarry, $\mathrm{D}_{3} \mathrm{fm}_{1}$ & $\mathrm{D} 02-2 / 12$ & Jablonnodus erectus & -23.09 & $\mathrm{n} / \mathrm{a}$ \\
\hline Russkiy Brod Quarry, $D_{3} \mathrm{fm}_{1}$ & D02-2/12 & Mitrellataxis & -23.64 & $\mathrm{n} / \mathrm{a}$ \\
\hline Russkiy Brod Quarry, $D_{3} \mathrm{fm}_{1}$ & D02-2/12 & Jablonnodus erectus & -26.33 & $\mathrm{n} / \mathrm{a}$ \\
\hline Russkiy Brod Quarry, $D_{3} \mathrm{fm}_{1}$ & D02-2/12 & Mitrellataxis & -26.8 & $n / a$ \\
\hline Russkiy Brod Quarry, $D_{3} \mathrm{fm}_{1}$ & D02-2/12 & Jablonnodus erectus & -28.08 & $\mathrm{n} / \mathrm{a}$ \\
\hline Russkiy Brod Quarry, $D_{3}$ fm $_{1}$ & D02-3/12 & Jablonnodus erectus & -26.34 & $\mathrm{n} / \mathrm{a}$ \\
\hline Russkiy Brod Quarry, $D_{3} \mathrm{fm}_{1}$ & $\mathrm{D} 02-3 / 12$ & Icriodus cornutus & -23.12 & $n / a$ \\
\hline Russkiy Brod Quarry, $\mathrm{D}_{3} \mathrm{fm}_{1}$ & $\mathrm{D} 02-3 / 12$ & Mitrellataxis & -27.88 & $\mathrm{n} / \mathrm{a}$ \\
\hline Syas River section, $D_{3} f_{1}$ & $5174 a / 1$ & Youngquistognathus praeangustidiscus & -25.92 & $\mathrm{n} / \mathrm{a}$ \\
\hline
\end{tabular}

